\title{
Politik Hukum Pengaturan Masyarakat Hukum Adat (Studi Putusan Mahkamah Konstitusi)
}

\author{
Zayanti Mandasari \\ Pascasarjana Fakultas Hukum Universitas Islam Indonesia \\ Jl. Cik Di Tiro No. 1 Yogyakarta \\ smanda79@yahoo.com
}

\begin{abstract}
This study discussed the problem of the indigenous law community existence in Indonesia, and the dynamics of the indigenous law community viewed from the Acts of Constitutional Court. This study was focused to analyze two matters, namely: First, how is the existence of the indigenous law community in Indonesia? Second, how does the indegenous law community take the Acts of Constitutional Court? This study used the statute approach. In addition, case study approach was also used to find the ratio decidendi used by the judges of Constitutional Court in adjudicating the statute test case related to the indigenous law community. The result of the research concluded that: first, the existence of the indigenous law community in Indonesia had already been accomodated in the prevailing laws of regulations including the 1945 Constitution of Republic Indonesia, Acts, Regional Regulations, Governors' Decrees, and Heads of Regions' Decrees. Second, the law politics of the indigenous law community took the Acts of Constitutional Court as strengthening the existence of the indigenous law community in Indonesia by providing the interpretation or explanation.
\end{abstract}

Key words : Indigenous law community, constitutional court, law politics

\begin{abstract}
Abstrak
Penelitian ini mengangkat permasalahan eksistensi masyarakat hukum adat di Indonesia, serta dinamika masyarakat hukum adat dilihat dari putusan Mahkamah Konstitusi. Penelitian ini difokuskan menganalisis dua hal yakni: Pertama, bagaimana eksistensi masyarakat hukum adat di Indonesia ? Kedua, bagaimana politik hukum masyarakat hukum adat melalui putusan Mahkamah Konstitusi? Penelitian ini menggunakan pendekatan perundang-undangan (statute approach). Selain itu juga digunakan pendekatan kasus yang digunakan untuk mengetahui ratio decidendi yang digunakan oleh hakim Mahkamah Konstitusi dalam memutus perkara pengujian undang-undang yang terkait dengan masyarakat hukum adat. Hasil penelitian menyimpulkan: pertama, keberadaan masyarakat hukum adat di Indonesia telah diakomodir di berbagai lingkup peraturan perundang-undangan, baik dalam UUD 1945, Undang-Undang, Peraturan Daerah, Surat Keputusan Gubernur, dan Surat Keputusan Bupati. Kedua, politik hukum masyarakat hukum adat melalui putusan Mahkamah Konstitusi memperkokoh keberadaan masyarakat hukum adat di Indonesia dengan memberikan berbagai tafsir atau penjelasan.
\end{abstract}

Kata kunci: Masyarakat hukum adat, mahkamah konstitusi, politik hukum. 


\section{Pendahuluan}

Masyarakat hukum adat ${ }^{1}$ merupakan bagian dari masyarakat Indonesia. Perlu diingat bahwa sebelum terbentuknya wilayah nusantara (Indonesia), sebagai sebuah Negara Kesatuan Republik Indonesia, masyarakat hukum adat telah lahir dan tumbuh. Sujoro Wignjodipuro ${ }^{2}$ mengatakan bahwa masyarakat hukum adat sebelum kemerdekaan telah hidup berdampingan dengan Hindia Belanda, pada saat itu pemerintah Hindia Belanda mengakui dan mengatur masyarakat hukum adat dalam pemerintahan otonomi serta madebewind-nya. Pasca kemerdekaan, masyarakat hukum adat bahkan diakui dengan dimasukkannya dalam penjelasan UUD 1945 (sebelum amandemen) dalam penjelasannya menyatakan bahwa: "Dalam teritoir Negara Indonesia terdapat lebih kurang 250 zelfbesturende landschappen dan volkgemeenschappen, seperti desa di Jawa dan Bali, nagari di Minangkabau, dusun dan marga di Palembang dan sebagainya".

Daerah-daerah tersebut mempunyai susunan asli dan oleh karenanya dapat dianggap sebagai daerah yang bersifat istimewa. ${ }^{3}$ Pasca amandemen UUD 1945, masyarakat hukum adat diakomodir dalam Pasal 18B ayat (2) yang mengatakan: "Negara mengakui dan menghormati kesatuan-kesatuan masyarakat hukum adat serta hak-hak tradisionalnya sepanjang masih hidup dan sesuai dengan perkembangan masyarakat dan prinsip Negara Kesatuan Republik Indonesia, yang diatur dalam undang-undang." Dimasukkannya masyarakat hukum adat dalam UUD 1945 merupakan wujud dari pengakuan negara terhadap eksistensi masyarakat hukum adat. Selain itu, Indonesia juga telah meratifikasi Undang-Undang No. 11 Tahun 2005 tentang Ratifikasi Kovenan Hak Ekonomi dan Budaya. Oleh karena itu, maka negara mempunyai kewajiban dalam rangka to respect, to protect dan to fulfill

${ }^{1}$ Hazairin mendefinisikan masyarakat hukum adat merupakan "kesatuan-kesatuan kemasyarakatan yang mempunyai kelengkapan-kelengkapan untuk sanggup berdiri sendiri, yaitu mempunyai kesatuan hukum, kesatuan pengusaha dan kesatuan lingkungan hidup berdasarkan hak bersama atas tanah dan air bagi semua anggotanya.Surjono Wignjodipuro juga mengatakan bahwa masyarakat hukum adat merupakan kesatuan-kesatuan yang mempunyai tata susunan yang teratur dan kekal serta memiliki pengurus sendiri dan kekayaan sendiri, baik kekayaan materiil maupun kekayaan yang immaterial. Lihat dalam Soerjono Seokanto, Kedudukan Kepala Desa Sebagai Hakim Perdamaian, Cetakan pertama, Rajawali Press, Jakarta, 1986, hlm. 11. Lihat juga dalam Surojo Wignjodipuro, Pengantar Azas-azas Hukum Adat, Ed. II, Alumni, Bandung, 1973, hlm. 84. Menurut Jawahir Thontowi, bahwa masyarakat hukum adat merupakan sekelompok orang yang terikat oleh tatanan hukum adatnya sebagai warga negara bersama persektuan hukum karena kesamaan tempat tinggal ataupun atas dasar keturunan. Lihat dalam "Perlindungan dan Pengakuan Masyarakat Hukum Adat dan Tantangannya dalam Hukum Indonesia”, Jurnal Hukum Ius Qua Lustum, No. 1 Vol. 20, Tahun 2013, hlm. 25.

${ }^{2}$ Ibid., hlm. 19.

${ }^{3}$ Bagir Manan, Menyongsong Fajar Otonomi Daerah, Cetakan kedua, PSH FH UII, Yogyakarta, 1999, hlm. 158 
atas hak tersebut dalam hal ini adalah untuk respect, protect dan fulfill terhadap hakhak masyarakat hukum adat. Salah satu bentuk nyata dari hak masyarakat hukum adat adalah hak kepemilikan terhadap tanah adat atau yang sering disebut dengan 'hak ulayat'. ${ }^{4}$

Hak ulayat adalah hak masyarakat hukum adat sebagai lembaga hidup bersama dan dikelola untuk kepentingan bersama anggota masyarakat hukum adat (communal bezitrecht). ${ }^{5}$ Hak ulayat merupakan salah satu bentuk dari pengakuan eksistensi masyarakat hukum adat di Indonesia, karena di berbagai tempat di Indonesia, interaksi antara masyarakat adat dengan hutan tercermin dalam model-model pengelolaan masyarakat adat atas hutan yang pada umumnya didasarkan pada hukum adat. Adanya pengakuan terhadap hak ulayat tersebut, bukannya membuat masyarakat hukum adat dapat hidup tenang dalam berinteraksi dilingkungannya, tetapi seringkali masyarakat hukum adat justru "terusir" dari tanahnya sendiri, hal ini dapat dilihat dari data yang tercatat oleh Perkumpulan untuk Pembaharuan Hukum Berbasis Masyarakat dan Ekologis (Huma), yang menyatakan bahwa tercatat 91.968 orang dari 315 komunitas adat masyarakat di Indonesia menjadi korban dalam konflik sumberdaya alam dan pertanahan. Konflik terjadi di 98 kota/kabupaten di 22 provinsi dengan jumlah konflik mencapai 232 kasus. ${ }^{6}$ Hal ini dapat dikaitkan dengan situasi ekonomi pasar yang semakin bebas, sehingga keberpihakan 'negara' justru pada pemilik modal, hal inilah yang menyebabkan ketidaknetralan peraturan perundang-undangan, sehingga 'menggadaikan' jaminan kepastian hukum bagi masyarakat hukum adat.

Fenomena di atas, tentu sangat bertentangan dengan adanya pengakuan dan penghormatan terhadap masyarakat hukum adat di Indonesia. Beragamnya perlakuan yang cenderung 'buruk' terhadap masyarakat hukum adat tersebut, sudah sejak lama terjadi dan terus berulang. Hal tersebut bahkan mendapat perhatian bagi

\footnotetext{
${ }^{4}$ Hak ulayat merupakan hak yang berhubungan dengan tanah atau bumi yang memiliki kejelasan lokasi dan batas-batasnya, misalnya tanah, hutan, laut pinggiran pantai, danau, lebak sungai-sungai kecil, sumber air dll, serta segala manfaat yang mereka ambil menurut aturan adat. Pengaturan mengenai hak ulayat (selanjutnya disebut tanah adat) sebenarnya telah diatur dalam Undang-Undang No. 5 Tahun 1960 tentang Pokok Agraria. Undang-undang tersebut secara garis besar mengatur seluruh penyelenggaraan pertanahan pada zamannya.

${ }^{5}$ Sjahmunir AM, Pemerintahan Nagari dan Tanah Ulayat, Andalas University Press, Padang, 2006, hlm. 150.

${ }^{6}$ Lihat, Tempo, Senin, 28 Oktober 2013, id.berita.vahoo.com/korban-konflik-pertanahan-capai-91-968-orang073753758.html, Korban Konflik Pertanahan Capai 91.968 Orang. konflik sektor perkebunan merupakan konflik terbanyak, disusul kehutanan dan pertambangan. Konflik perkebunan terjadi 119 kasus dengan luasan 415 ribu hektare, sementara itu konflik kehutanan terjadi 72 kasus dengan hampir 1.3 juta hektar di 17 provinsi dan konflik pertambangan 17 kasus dengan luasan mencapai 30 ribu hektar.
} 
berbagai pihak yang fokus pada masyarakat hukum adat, seperti di 1993 muncul kelompok yang menamakan dirinya Jaringan Pembelaan Hak-hak Masyarakat Adat (JAPHAMA), 1999 muncul suatu gerakan masyarakat yang menamakan dirinya Aliansi Masyarakat Nusantara (AMAN) yang merupakan sebuah organisasi nasional masyarakat adat tingkat nasional yang pertama di Indonesia sebagai upaya mempengaruhi kebijakan pemerintah. Bahkan pada saat itu, AMAN dengan tegas mengatakan "kalau negara tidak mengakui kami, kami pun tidak akan mengakui negara”, yang pada akhirnya dijadikan semboyan provokatif AMAN yang didengungkan dalam Kongres Masyarakat Adat Nusantara yang pertama 1999.?

Tujuan dari kelompok-kelopmpok tersebut adalah mempertahankan dan mengangkat kembali 'keluhuran' masyarakat hukum adat yang ada di Indonesia dan mencegah serta melindungi masyarakat adat dari kesewenang-wenangan negara atau dengan kata lain mewujudkan keadilan bagi masyarakat hukum adat. Oleh karena itu, kelompok tersebut aktif menjadi 'fasilitator' bagi masyarakat hukum adat dalam mempertahankan hak-hak konstitusionalnya yang telah jelas diatur dalam UUD 1945. Salah satu caranya adalah mengajukan uji materi undang-undang yang di dalamnya terdapat muatan yang merugikan masyarakat adat dan bahkan bertentangan dengan UUD1945 kepada Mahkamah Konstitusi sebagai the guardian of constitution. Agar terwujud keadilan bagi masyarakat hukum adat yang sesungguhnya, bukan hanya berhenti sebatas norma tertulis dalam UUD 1945 ataupun dalam peraturan perundang-undangan lainnya.

\section{Rumusan Masalah}

Berdasarkan latar belakang permasalahan di atas, maka penelitian ini difokuskan menganalisa dua hal penting yakni: Pertama, bagaimana eksistensi masyarakat hukum adat di Indonesia? Kedua, bagaimana politik hukum pengaturan masyarakat hukum adat melalui putusan Mahkamah Konstitusi?

\section{Tujuan Penelitian}

Berdasarkan dua permasalahan tersebut di atas, maka penelitian ini bertujuan untuk, pertama, untuk menjelaskan eksistensi masyarakat hukum adat di Indonesia. hlm. 2

${ }^{7}$ Jamie S. Davidson, dkk, Adat Dalam Politik Indonesia, Yayasan Obor Indonesia, Edisi-1,KITLV-Jakarta, 2010, 
Kedua, mengetahui dan menganalisis putusan Mahkamah Konstutusi terkait pengaturan masyarakat hukum adat di Indonesia.

\section{Metode Penelitian}

Penelitian ini menggunakan bahan hukum primer terdiri atas: Undang-Undang No. 5 Tahun 1960 tentang Peraturan Dasar Pokok-Pokok Agraria, Undang-Undang No. 41 Tahun 1999 tentang Kehutanan, Undang-Undang No. 1 Tahun 2004 tentang Sumber Daya Air, Undang-Undang No. 18 Tahun 2004 tentang Perkebunan, UndangUndang No. 24 Tahun 2003 tentang Mahkamah Konstitusi, dan berbagai peraturan perundang-undangan lain yang berkaitan dengan objek penelitian ini, serta putusan Mahkamah Konstitusi yang terkait dengan eksistensi masyarakat hukum adat, yakni Putusan Mahkamah Konstitusi Nomor. 31/PUU-V/2007; Putusan Mahkamah Konstitusi Nomor. 47-81/PHPU.A/VII/2009; Putusan Mahkamah Konstitusi Nomor.3/PUU-VII/2010; Putusan Mahkamah Konstitusi Nomor. 45/PUU-IX/2011; Putusan Mahkamah Konstitusi Nomor. 35/PUU-X/2012. Sedangkan bahan hukum sekunder yang digunakan terdiri atas buku-buku tentang masyarakat hukum adat, hasil penelitian dan jurnal-jurnal ilmiah.

Penelitian ini menggunakan pendekatan undang-undangan (statute approach) karena meneliti peraturan perundang-undangan yang terkait dengan objek penelitian yakni masyarakat hukum adat di Indonesia. Selain itu juga digunakan pendekatan kasus yang digunakan untuk mengetahui ratio decidendi, yaitu alasan hukum yang digunakan oleh hakim (Mahkamah Konstitusi), ${ }^{8}$ dalam memutus permohonan pengujian sejumlah UU yang terkait dengan masyarakat hukum adat.

\section{Hasil dan Pembahasan}

\section{Masyarakat Hukum Adat di Indonesia}

Istilah masyarakat adat di Indonesia dalam literatur dan perundang-undangan terdapat beberapa penyebutan, seperti ada yang menyebutnya dengan 'persekutuan adat', 'masyarakat adat', dan 'masyarakat hukum adat'. Meskipun demikian, hal ini tidak menjadi alasan untuk menegasikan keberadaan serta hak-hak yang dimiliki

\footnotetext{
${ }^{8}$ Peter Mahmud, Penelitian Hukum, Cetakan ke-7, Kencana, Jakarta, 2005, hlm. 119.
} 
oleh mereka. Dalam Undang-Undang No. 5 Tahun 1960 tentang Peraturan Dasar Pokok-Pokok Agraria (UUPA) telah mengatur eksistensi masyarakat hukum adat khususnya pada bidang hak ulayat. Pasal 2 ayat (4) mengatakan: "Hak menguasi dari negara di atas pelaksanaannya dapat dikuasai pada pemerintahan daerah swantara dan masyarakat-masyarakat hukum adat, sekedar diperlukan dan tidak bertentangan dengan kepentingan nasional, menurut ketentuan-ketentuan peraturan pemerintah". Selain dalam UUPA, istilah 'masyarakat adat' juga mulai meluas penggunaannya di kalangan organisasi non-pemerintah dan juga oleh pihak-pihak lain seperti pemerintah, sektor swasta dan media massa sejak istilah ini disepakati sebagai istilah yang digunakan untuk advokasi pembelaan masyarakat korban pembangunan di berbagai daerah oleh sejumlah oeranisasi non-pemerintah dalam sebuah lokakarya yang difasilitasi oleh Wahana Lingkungan Hidup (WALHI) dan mitra regionalnya di Tana Toraja pada $1993 .{ }^{9}$

Istilah ini juga disepakati sebagai padanan dari istilah indigenous peoples ketimbang berbagai istilah yang bersifat mendeskreditkan masyarakat adat, seperti masyarakat terpencil, peladang berpindah, masyarakat tradisional dan lainnya yang banyak digunakan dalam era Orde Baru. Selain itu, faktor sejarah juga berperan, dalam studi tentang masyarakat Indonesia dan sejarahnya dikenal dengan istilah 'masyarakat hukum adat' yang merupakan terjemahan langsung dari rechtsgemeenschappen, yang dicetuskan oleh Van Vollenhoven pada paroh pertama Abad 20, yang menyusul pengamatannya atas keberadaan 19 wilayah yang memiliki hukum adat di Indonesia pada masa itu. ${ }^{10}$

Istilah masyarakat hukum adat masih terus digunakan hingga sekarang dalam dokumen-dokumen resmi negara, seperti peraturan perundang-undangan. Dalam naskah UUD 1945 sebelum amandemen dapat ditemukan penggunaan istilah Zelfbesturendelandschappen dan Volksgemeenschappen, yang pertama dapat diterjemahkan sebagai daerah swapraja, yaitu kerajaan-kerajaan yang punya pemerintahan sendiri sedangkan yang kedua adalah self governing community seperti desa di Jawa, nagari di Sumatra dan lainnya. Akhirnya dikenal sebagai rechtsgemeenschappen yang diterjemahkan sebagai 'masyarakat hukum adat'. ${ }^{11}$ Definisi

\footnotetext{
${ }^{9}$ Emil Ola Kladen, "Masyarakat Adat", Dalam Eko Riyadi dan Syarif Nur Hidayat (editor), Vulnerable Groups: Kajian dan Mekanisme Pelindungannya, Cetakan pertama, Pusat Studi Hak Asasi Manusia Universitas Islam Indonesia (PUSHAM UII), Yogyakarta, 2012, hlm 377-378.

${ }^{10}$ Ibid., hlm. 379

${ }^{11}$ Ibid., istilah masyarakat hukum adat ini tidak diamini oleh semua orang, khususnya aktivis organisasi non
} 
terkait dengan masyarakat hukum adat kemudian dikembangkan oleh AMAN di kongresnya yang pertama di 1999, yaitu: sekelompok masyarakat yang hidup berdasarkan adal usul leluhur dalam suatu wilayah geografis tertentu, memiliki sistem nilai dan sosial budaya yang khas, berdaulat atas tanah dan kekayaan alamnya serta mengatur dan mengurus keberlanjutan kehidupannya dengan hukum dan kelembagaan adat. ${ }^{12}$ Saafroedin Bahar dan Ruswiati Suryasaputra mendefinisikan masyarakat hukum adat sebagai entitas antropoligis yang tumbuh secara alamiah pada suatu bagian muka bumi tertentu, dan terdiri dari berbagai komunitas primordial berukuran kecil yang warganya mempunyai hubungan darah satu sama lainnya. ${ }^{13}$

Pengakuan terhadap keberadaan masyarakat hukum adat mendapat tempat khusus di dalam UUD 1945 yakni dalam Pasal 18B ayat (2) dan Pasal 28I ayat (3) menjadi dasar konstitusional yang paling sering dirujuk ketika membicarakan keberadaaan dan hak-hak masyarakat adat. Pasal 18B ayat (2) UUD 1945 menyatakan: "Negara mengakui dan menghormati satuan-satuan masyarakat hukum adat besrta hak-hak tradisionalnya sepanjang masih hidup dan sesuai dengan prinsip perkembangan masyarakat dan prinsip Negara Kesatuan Republik Indonesia, yang diatur dalam undang-undang." Sementara itu Pasal 28I ayat (3) UUD 1945 menyatakan:"identitas budaya dan hak masyarakat tradisional dihormati selaras dengan perkembangan zaman dan peradaban."

Dalam peraturan perundang-undangan lainnya masyarakat hukum adat dimuat dalam Undang-Undang No. 41 Tahun 1999 tentang Kehutanan, Undang-Undang No. 1 Tahun 2004 tentang Sumber Daya Air, Undang-Undang No. 18 Tahun 2004 tentang Perkebunan, bahkan dalam Undang-Undang No. 24 Tahun 2003 tentang Mahkamah Konstitusi,masyarakat hukum adat ditempatkan sebagi pihak khusus yang dapat menjadi pemohon dalam pengujian undang-undang. Dalam Pasal 51 ayat (1) disebutkan bahwa:"Pemohon adalah pihak yang menganggap hak dan/atau kewenangan konstitusionalnya dirugikan oleh berlakunya undang-undang, yaitu: a. perorangan warga negara Indonesia; b. kesatuan masyarakat hukum adat sepanjang masih hidup dan sesuai dengan perkembangan masyarakat dan prinsip

pemerintah lebih memilih menggunakan istilah 'masyarakat adat', dengan alasan bahwa istilah 'masyarakat hukum adat' pada akhirnya hanya akan mempersempit entitas masyarakat adat sebatas entitas hukum. Lihat dalam Rikardo Simarmata, Menyongsong Berakhirnya Abad Masyarakat Adat: Resistensi Pengakuan Bersyarat, 2004.

${ }^{12}$ Emil Ola Kladen, "Masyarakat ....., Op., Cit., hlm. 390.

${ }^{13}$ Saafroedin Bahar dan Ruswiati Suryasaputra, "Kebijakan Negara dalam Rangka Pengakuan, Penghormatan dan Perlindungan Masyarakat (Hukum) Adat di Indonesia", dalam Perlindungan Hak Konstitusional Masyarakat Hukum Adat, Sekretariat Nasional Masyarakat Hukum Adat, Pekanbaru, 2009, hlm. 116. 
Negara Kesatuan Perublik Indonesia yang diatur dalam undang-undang; c. badan hukum publik atau privat; atau d. lembaga negara." Penghormatan terhadap masyarakat hukum adat ternyata tak hanya sebatas pengakuan, masyarakat hukum adat bahkan memiliki kedudukan hukum (legal standing) sebagai pihak yang dapat berperkara di Mahkamah Konstitusi dilekati dengan persyaratan sesuai dengan Pasal 18B ayat (2) UUD 1945 seperti yang telah dipaparkan di atas. Mahkamah Konstitusi pertama kali memberikan penjelasan terhadap empat syarat keberadaan kesatuan masyarakat hukum adat, dalam putusan perkara No. 31/PUU-V/2007 mengenai Pengujian Undang-Undang No. 31 Tahun 2007 tentang Pembentukan Kota Tual di Provinsi Maluku. Dalam permohonan tersebut terdapat pihak yang mengajukan diri dengan legal standing sebagai masyarakat adat. Karena permohonan demikian, maka Mahkamah Konstitusi menjelaskan terlebih dahulu legal standing pemohon dengan memberikan makna tehadap Pasal 18B ayat (2) UUD 1945 yang menjadi dasar konstitusional keberadaan masyarakat adat.

Penjelasan Mahkamah Konstitusi terhadap empat syarat konstitusionalitas kesatuan masyarakat hukum adat dalam Pasal 18B ayat (2) UUD 1945 adalah sebagai berikut: ${ }^{14}$

Tabel

\begin{tabular}{|c|c|c|}
\hline No & Unsur & Penjelasan \\
\hline 1 & Masih hidup; & $\begin{array}{l}\text { Kesatuan masyarakat hukum adat untuk dapat } \\
\text { dikatakan secara de facto masih hidup (actual exixtence) } \\
\text { baik yang bersifat territorial, genealogis, maupun yang } \\
\text { bersifat fungsional setidak-tidaknya mengandung } \\
\text { unsur-unsur: } \\
\text { 1. Adanya masyarakat yang warganya memiliki } \\
\text { perasaan kelompok (in-group feeling); } \\
\text { 2. Adanya pranata pemerintahan adat; } \\
\text { 3. Adanya harta kekayaan dan/atau benda-benda adat; } \\
\text { 4. Adanya perangkat norma hukum adat. Khusus } \\
\text { pada kesatuan masyarakat hukum adat yang } \\
\text { bersifat territorial juga terdapat unsur adanya } \\
\text { wilayah tertentu. }\end{array}$ \\
\hline
\end{tabular}

${ }^{14}$ Lihat lebih lanjut dalam putusan MK No. 31/PUU-V/2007 mengenai Pengujian Undang-Undang No. 31 Tahun 2007 tentang Pembentukan Kota Tual Di Provinsi Maluku. Lihat juga dalam Yance Arizona, "Konstutusionalisme Agraria (Mahkamah Konstitusi sebagai arena memperjuangkan hak waga negara atas dan sumber daya alam lainnya)", disampaikan pada Konferensi Nasional Mabkamah Konstitusi dan Perlindungan Hak. Warga Negara, Jakarta, 18-19 November 2013, bekerjasama dengan Indonesia Constitusional Democracy Forum, Institute Democracy and Peace, dan German Embassy Jakarta, hlm. 24. 


\begin{tabular}{|c|c|c|}
\hline No & Unsur & Penjelasan \\
\hline 2 & $\begin{array}{l}\text { Sesuai dengan } \\
\text { perkembangan } \\
\text { masyarakat; }\end{array}$ & $\begin{array}{l}\text { Kesatuan masyarakat hukum adat beserta hak-hak } \\
\text { tradisionalnya dipandang sesuai dengan perkembangan } \\
\text { masyarakat apabila kesatuan masyarakat hukum adat } \\
\text { tersebut: } \\
\text { 1. Keberadaannya telah diakui berdasarkan undang- } \\
\text { undang yang berlaku sebagai pencerminan } \\
\text { perkembangan nilai-nilai yang dianggap ideal dalam } \\
\text { masyarakat dewasa ini, baik undang-undang yang } \\
\text { bersifat umum maupun yang bersifat sektoral, seperti } \\
\text { bidang agrarian, kehutanan, perikanan, dan lain-lain } \\
\text { maupun dalam peraturan daerah; } \\
\text { 2. Substansi hak-hak tradisional tersebut diakui dan } \\
\text { dihormati oleh warga kesatuan masyarakat yang } \\
\text { bersangkutan maupun masyarakat yang lebih luas, } \\
\text { serta tidak bertentangan dengan hak-hak asasi } \\
\text { manusia. }\end{array}$ \\
\hline 3 & $\begin{array}{l}\text { Sesuai dengan } \\
\text { prinsip Negara } \\
\text { Kesatuan Republik } \\
\text { Indonesia }\end{array}$ & $\begin{array}{l}\text { Kesatuan masyarakat hukum adat beserta hak-hak } \\
\text { tradisionalnya sesuai dengan prinsip Negara Kesatuan } \\
\text { Republik Indonesia apabila kesatuan masyarakat } \\
\text { hukum adat tersebut tidak mengganggu eksistensi } \\
\text { Negara Kesatuan Republik Indonesia sebagai sebuah } \\
\text { kesatuan politik dan kesatuan hukum yaitu: } \\
\text { 1. Keberadaannya tidak mengancam kedaulatan dan } \\
\text { integritas Negara Kesatuan Republik Indonesia; } \\
\text { 2. Substansi norma hukum adatnya sesuai dan tidak } \\
\text { bertentangan dengan peraturan perundang- } \\
\text { undangan. }\end{array}$ \\
\hline 4 & $\begin{array}{l}\text { Diatur dalam } \\
\text { undang-undang }\end{array}$ & Adanya pengaturan berdasarkan undang-undang. \\
\hline
\end{tabular}

Dalam putusan Mahkamah Konstitusi No. 31/PUU-V/2007 tersebut, terdapat hal yang penting, karena Mahkamah menegaskan bahwa “...pengakuan keberadaan masyarakat hukum adat sebagai penyandang hak atau sebagai subjek hukum merupakan hal yang fundamental. Hal penting dan fundamental tersebut adalah masyarakat hukum adat tersebut secara konstitusional diakui dan dihormati sebagai penyandang hak yang demikian tentunya dapat pula dibebani hukum di dalam suatu masyarakat yang telah menegara maka masyarakat hukum adat haruslah mendapat perhatian sebagaimana subjek hukum yang lain ketika hukum hendak mengatur, terutama mengatur dalam rangka pengalokasian sumber-sumber kehidupan." 
Penggalan pertimbangan putusan Mahkamah Konstitusi di atas menegaskan keberadaan masyarakat hukum adat sebagai subjek hukum yang khas. Kekhasan masyarakat hukum adat sebagai subjek hukum karena ia bersifat kesatuan/ kelompok yang menjadikan nilai-nilai adat dan kesamaan hak tradisional termasuk atas wilayah tertentu sebagai syarat keberadaannya. ${ }^{15}$ Masyarakat hukum adat juga telah diakomodir dalam berbagai peraturan dalam lingkup daerah. Kabupaten Kampar Riau misalnya telah mengakomodir masyarakat adat dan hukum adat Kenegrian Kuntu dalam Peraturan daerah kabupaten Kampar No. 12 Tahun 1999 tentang Hak Tanah Ulayat (Perda). Dalam Perda tersebut dijelaskan bahwa masyarakat adat Kenegrian Kuntu adalah masyarakat hukum adat. Peraturan Daerah Lebak No. 32 Tahun 2001 tentang Perlindungan Hak Ulayat Masyarakat Baduy.

Selain itu, terdapat Perda No. 6 Tahun 1986 tentang Desa Adat dan Perda No. 3 Tahun 2001 tentang Desa Pakraman, dua instrumen pengakuan terhadap masyarakat hukum adat ini bahkan di klaim sebagai perlawanan dan keberhasilan eksekutif dan legislatif Bali terhadap pemerintahaan pada saat itu. ${ }^{16}$ Perlawanan yang dimaksud adalah perlawanan terhadap lahirnya Undang-Undang No. 5 Tahun 1979 tentang Pemerintahan Desa. Dalam UU Desa tersebut menyebutkan bahwa desa adalah suatu wilayah yang ditempati oleh sejumlah penduduk sebagai kesatuan masyarakat, termasuk di dalamnya masyarakat hukum yang mempunyai organisasi pemerintahan terendah langsung di bawah camat dan berhak menyelenggarakan rumah tangganya sendiri dalam ikatan Negara Kesatuan Republik Indonesia. Dengan demikian Kepala Desa adalah penguasa tunggal di desa ${ }^{17}$, dengan konsep kepala desa sebgai penguasa tunggal di desa tersebut, tampak bahwa masyarakat desa di Indonesia terhegemoni oleh pandangan itu, dan membawa akibat pada merosotnya peran atau wibawa lembaga desa adat. ${ }^{18}$

Selain diakomodir dalam UUD 1945, Undang-Undang, dan Peraturan Daerah, seperti yang telah dipaparkan diatas, ternyata masyarakat hukum adat di daerah lain yang juga telah diakomodir dalam konteks lokal yakni, Karapatan Adat Nagari, yang diatur dalam Surat Keputusan Gubernur No. 15/GSB/1968 yang memuat tentang struktur pemerintahan Nagari yang terdiri dari Wali Nagari dan Dewan Perwakilan

${ }^{15}$ Ibid.

${ }^{16}$ I Wayan Wesna Astara, Pertarungan Politik. Hukum Negara dan Politik Kebudayaan (Otonomi Desa Adat di Bali, Udayana University Press, 2010, Bali, hlm. 32

${ }^{17}$ Pasal 10 ayat (1) UU No. 5 Tahun 1979.

${ }^{18}$ I Wayan Wesna Astara, Pertarungan Politik...., Op, Cit. hlm. 33 
Rakyat Nagari. Masyarakat hukum adat Kesepuhan Cisitu, dasar pengakuan masyarakat hukum adat Kesepuhan Cisitu ini adalah Surat Keputusan Bupati Lebak No. 430/ Kep.318/Disporabudpar/2010 tentang Pengakuan Keberadaan Masyarakat Hukum Adat Cisitu Kesatuan Sesepih Adat Cisitu Banten Kidul di Kabupaten Lebak.

Berdasarkan pembahasan di atas, dapat ditarik kesimpulan bahwa keberadaan masyarakat hukum adat di Indonesia telah diakomodir di berbagai lingkup pengaturan, baik dalam UUD 1945, Undang-Undang, Peraturan Daerah, Surat Keputusan Gubernur, dan Surat Keputusan Bupati. Bahkan hak-hak masyarakat hukum adat dan keberadaannya tersebut telah dijabarkan oleh Mahkamah Konstitusi dalam putusannya sebagai bentuk ketegasan pengakuan, penghormatan dan perlindungan terhadap masyarakat hukum adat yang ada di Indonesia.

\section{Politik Hukum Masyarakat Hukum Adat Melalui Putusan Mahkamah Konstitusi}

Politik hukum terdiri dari dua kata yaitu politik dan hukum. Antara kedua kata ini terdapat hubungan yang erat walaupun masing-masing mempunyai pengertian yang berbeda. Maurice Duverger mengatakan bahwa 'politic political in its usual connotation is a concept dealing with the state' (pengertian yang lazimnya diberikan kepada politik merupakan suatu konsepsi yang berhubungan dengan negara. ${ }^{19}$ Hukum dan politik memang dua hal yang sulit untuk dipisahkan. Keduanya memiliki hubungan timbal-balik yang tidak mungkin dapat dihindari. Di satu sisi hukum berkepentingan dengan hasil yang akan diperolehnya melalui pengaturan itu, dan oleh karenanya ia harus paham tentang seluk beluk masalah yang diaturnya, sedangkan di sisi lain ia juga harus menyadari, bahwa faktor-faktor dan kekuatan-kekuatan di luar hukum akan memberikan beban pengaruhnya pula terhadap hukum serta proses bekerjanya. ${ }^{20}$

Antara hukum dan politik terdapat hubungan kausalitas yakni: pertama, hukum determinan atas politik dalam arti bahwa kegiatan-kegiatan politik diatur oleh dan harus tunduk pada aturan-aturan hukum. Kedua, politik determinan atas hukum, karena hukum merupakan hasil atau kristalisasi dari kehendak-kehendak politik yang saling berinteraksi dan saling bersaingan. Ketiga, politik dan hukum sebagai subsistem kemasyarakatan berada pada posisi yang derajat determinasinya

${ }^{19}$ Maurice Duverger, The Study of Political (translated by Robert Wagner), (London, Thimas Nelson and Sous Ltd, 1979), hlm. 12. Dikutip kembali oleh A.S.S Tambunan, Politik. Hukum Berdasarkan UUD 1945, Puporis, Jakarta, 2002, hlm. 2.

${ }^{20}$ Satjipto Rahardjo, Hukum dan Masyarakat, Angkasa, Bandung, 1979, hlm. 16. 
seimbang antara yang satu dengan yang lain, karena meskipun hukum merupakan produk keputusan politik tetapi begitu hukum ada maka semua kegiatan politik harus tunduk pada aturan-aturan hukum. ${ }^{21}$ Hirsch Ballin mengatakan bahwa politik hukum adalah kebijaksanaan negara untuk menerapkan hukum. ${ }^{22}$ Teuku Mohammad Radhie, berpendapat bahwa politik hukum adalah pernyataan kehendak penguasa negara mengenai hukum yang belaku di wilayahnya dan mengenai arah kemana hukum hendak diperkembangkan. ${ }^{23}$ Abdul Hakim Garuda Nusantara mengatakan bahwa politik hukum adalah politik pembangunan hukum, sedangkan Mahfud MD mengatakan bahwa politik hukum adalah legal policy yang akan atau telah dilaksanakan secara nasional oleh pemerintah Indonesia yang meliputi, pertama, pembangunan hukum yang berintikan pembuatan dan pembaruan terhadap materi-materi hukum agar dapat sesuai dengan kebutuhan, kedua, pelaksanaan ketentuan hukum yang telah ada termasuk penegasan fungsi lembaga dan pembinaan para penegak hukum. ${ }^{24}$

Mahkamah konstitusi merupakan lembaga yang dibentuk untuk mengawal dan menjaga agar konstitusi sebagai hukum tertinggi (the supreme law of the land) benarbenar dijalankan atau ditegakkan dalam penyelenggaraan kehidupan kenegaraan sesuai dengan prinsip-prinsip negara hukum. ${ }^{25}$ Mahkamah Konstitusi dengan segala kewenangannya dan kedudukannya sebagai salah satu penyelenggara kekuasaan kehakiman merupakan perwujudan fungsi penegakan prinsip-prinsip negara hukum, konstitusi, dan perlindungan hak asasi manusia berdasarkan UUD 1945. Mahkamah Konstitusi sebagai penafsir konstitusi, hendaknya memberikan perlindungan dan keadilan bagi setiap warga negara yang merasa hak konstitusionalnya dilanggar oleh adanya undang-undang. Mahkamah Konstitusi dalam berbagai putusan menunjukkan bahwa putusannya itu adalah hukum responsif dalam mewujudkan keadilan bagi warga negara. Responsif disini dimaknai seperti yang dikemukakan oleh Nonet dan Selznik yaitu the souvereignity of purpose. Nonet dan Selznick menyatakan bahwa hukum itu harus berorientasi terhadap tujuan. ${ }^{26}$ Nonet dan Selznick juga beranggapan bahwa

\footnotetext{
${ }^{21}$ Mahfud MD, Politik Hukum di Indonesia, LP3ES, Jakarta, hlm. 16.

22 A.S.S Tambunan, Politik. Hukum..., Op. Cit, hlm. 10.

${ }^{23}$ Ibid.

${ }^{24}$ Mahfud MD, Politik. Hukum... Op. Cit, hlm. 9.

${ }^{25}$ Jimly Asshiddiqie, Mahkamah Konstitusi dan Cita Negara Hukum Indonesia, opini, http// www.pemantauperadilan.com, diakses pada 30 Desember 2013.

${ }^{26}$ Phillppe Nonet dan Philip Selznick, Law and Society in Transition Towards Responsive Law, New Jersey: Trascation Publishers, 2001, hlm. 78-80.
} 
hukum itu merupakan institusi sosial, yang oleh karena itu hukum dilihat lebih dari suatu sistem peraturan belaka, melainkan juga bagaimana hukum menjalankan fungsifungsi sosial dalam dan untuk masyarakatnya. ${ }^{27} \mathrm{Hal}$ ini senada dengan pandangan hukum progresif yang dikemukakan oleh Satjipto Rahardjo, yang mengatakan bahwa hukum itu bertolak dari pandangan kemanusiaan, manusia pada dasarnya adalah baik, memiliki sifat-sifat, kasih sayang serta kepedulian terhadap sesama. Dengan demikian hukum menjadi alat untuk menjabarkan dasar kemanusiaan tersebut. Hukum bukan raja, tetapi alat saja yang berfungsi memberikan rahmat kepada dunia dan manusia. Pandangan ini tidak ingin menjadikan hukum sebagai teknologi yang tidak bernurani, melainkan suatu institusi yang bermoral, dalam hal ini moral kemanusiaan. ${ }^{28}$

Asumsi dasar, bahwa hukum adalah untuk manusia serta ideal hukum progresif, hukum mempunyai tujuan besar berupa kesejahteraan dan kebahagiaan manusia, maka hukum selalu berada pada status law in the making. Hukum tidak ada untuk dirinya sendiri dan tidak bersifat final. Setiap tahap dalam perjalanan hukum adalah putusan-putusan yang dibuat guna mencapai ideal hukum. ${ }^{29}$ Oleh karena itu, pada dasarnya pengujian konstitusional yang dilakukan oleh Mahkamah Konstitusi sebagai lembaga peradilan bertujuan untuk mereduksi adanya kerugian hak konstitusional dikemudian hari tanpa ada kerugian konstitusional yang menyeluruh yang dilekatkan kepada pemohon, yang tujuan akhirnya adalah tidak hanya memberikan keadilan dalam lingkup prosedural saja, tetapi meliputi keadilan substantif bagi setiap warga negara, dalam hal ini khususnya bagi masyarakat hukum adat yang seringkali menjadi'objek' kesewenang-wenangan pemerintah.

\section{Pengakuan terhadap Hak-hak Politik Masyarakat Hukum Adat dalam Pelaksanaan Pemilu (Putusan No.47-81/PHPU.A/VII/2009)}

Hak konstitusional merupakan hak dasar bagi seluruh masyarakat Indonesia, tidak terkecuali bagi masyarakat hukum adat yang masih menjunjung tinggi nilainilai hukum adatnya. Seringkali hukum adat berbeda dengan hukum positif yang berlaku di Indonesia tetapi iti tidak boleh dijadikan alasan untuk menafikan hukum adat pada masyarakat adat di suatu daerah. Salah satu masyarakat yang masih

${ }^{27}$ Ibid.

${ }^{28}$ Satjipto Raharjdjo, Hukum Progresif (Sebuah Sintesa Hukum Indonesia), Genta Publishing, Cetakan I, Juli, 2009, Yogyakarta, hlm. 17.

${ }^{29}$ Ibid. 18 
memegang teguh nilai hukum adatnya adalah masyarakat adat di Kabupaten Yahukimo, Provinsi Papua. Masyarakat adat di Yahukimo menggunakan hukum adatnya dalam berbagai pola kehidupan, bahkan dalam pelaksanaan pemilihan umum mereka menggunakan hukum adatnya sendiri dan tidak berpedoman pada Undang-Undang No. 10 Tahun 2008 tentang Pemilu.

Salah satu bentuk hukum adat yang dijalankan oleh masyarakat adat di Yahukimo adalah Noken. Noken adalah cara mereka dalam melaksanakan pemungutan suara. Pada pemilu tahun 2009, masyarakat di Kabupaten Yahukimo terlibat dalam pemilu, namun dalam pelaksanaannya disesuaikan dengan mekanisme adat. Pencontrengan kertas suara diwakilkan oleh kepala-kepala suku. Pencontrengan tidak dilakukan di dalam bilik suara dan kertas suara yang dicontreng tersebut tidak dimasukkan ke dalam kotak suara, tapi dimasukkan ke dalam tas khas orang Papua yang disebut "Noken". Pemilihan model Noken ini terungkap dalam sidang perkara Nomor. 47-81/PHPU.A/VII/2009 di Mahkamah Konstitusi yang diajukan oleh dua orang pemohon, yaitu Pdt. Elion Numberi dan Hasbi Suaib, S.T. ${ }^{30}$ Sebenarnya yang dipersoalkan oleh dua pemohon ini adalah tentang perselisihan hasil pemilu untuk anggota DPD, bukan konstitusionalitas noken sebagai model pemilihan. Namun, mau tidak mau, pemilihan model noken ini terkait langsung dengan sahnya pemilihan dan jumlah suara yang diperselisihkan.

Gubernur Papua, Barnabas Suebu menyebutkan bahwa penggunaan noken sebagai pengganti kotak suara itu sendiri sudah berlangsung sejak pemilu 1971. Sistem noken di Papua 'dikuasai' oleh kepala suku. Artinya, kepala suku mendaftarkan anggota sukunya sebagai pemilih kepada petugas pendaftaran atau Pantarlih. Proses pendaftaran tersebut tidak dilakukan berdasar prinsip satu orang satu pendaftaran. Peran kepala suku di Papua sangat luar biasa, kalau tidak mau mengikuti kepala suku berarti perang.

Sebagian pihak beranggapan bahwa, Noken tersebut dapat menjadi kendala pelaksanaan pemilu demokratis bahkan sistem Noken juga melanggar asas-asas

${ }^{30}$ Lihat Putusan Mahkamah Konstitusi Nomor 47-81/PHPU.A/VII/2009, di dalamnya terdapat permohonan bahwa Pemohon adalah Calon Anggota Dewan Perwakilan Daerah Provinsi Papua yang meraih suara terbanyak ke enam berdasarkan Lampiran II.32. Surat Keputusan Komisi Pemilihan Umum (KPU) Nomor 255/Kpts/KPU/ TAHUN 2009 tentang Penetapan dan Pengumuman Hasil Pemilihan Umum Anggota Dewan Perwakilan Rakyat, Dewan Perwakilan Daerah, Dewan Perwakilan Rakyat Daerah Provinsi, dan Dewan Perwakilan Rakyat Daerah Kabupaten/ Kota Secara Nasional Dalam Pemilu Tahun 2009. Lampiran Keputusan Komisi Pemilihan Umum a qou menurut Pemohon cacat hukum karena terdapat ketidakcermatan penyusunan peringkat suara sah calon. Dalam susunan peringkat tersebut tidak terdapat peringkat 1 (satu), sehingga peringkat tertinggi adalah 2 (videbukti P-2). 
yang terdapat dalam UU Pemilu yakni asas langsung, bebas, dan rahasia. Tetapi tidak demikian halnya pandangan dari para Hakim Mahkamah Konstitusi. Dalam putusannya, Mahkamah berpendapat bahwa: "Mahkamah Konstitusi dalam kasus Yakuhimo tetap menghargai budaya masyarakat untuk melakukan pemilihan dengan cara pemilihan kolektif ('kesepakatan warga' atau 'aklamasi') telah diterima masyarakat". Dalam putusannya Mahkamah Konstitusi juga mendasarkan pada kondisi sosiologis masyarakat hukum adat di Yahukimo ${ }^{31}$, sehingga mengakomodir sebagian budaya lokal serta menerima dan mengakui hukum adat yang masih dipegang teguh (Noken) oleh masyarakat adat setempat dalam sistem pemilu yang bersifat nasional. Putusan Mahkamah Konstitusi tersebut secara tegas dan jelas menerima mekanisme pemilihan secara perwakilan aklamasi ala adat sebagai cara yang sah, konstitusional, dan tidak bertentangan dengan mekanisme pemilihan ala one man one vote yang sudah diterapkan sejak pemilihan presiden secara langsung pada 2004 dan pilkada sejak 2005.

Model pemilihan umum dengan Noken sebenarnya mempertegas peranan adat dalam membangun demokrasi. Model noken dilakukan dengan cara musyawarah antara kepala-kepala suku dengan masyarakat. Masyarakat melakukan musyawarah untuk menentukan partai apa dan siapa yang akan dipilih menjadi wakil mereka di parlemen. Setelah dilakukan musyawarah, kepala suku ditugaskan untuk mewakili pemilih melakukan penyontrengan. Kertas yang sudah dicontreng dimasukkan dalam Noken berdasarkan pilihan yang sudah disepakati. Bahkan menurut Achmad Sodiki $^{32}$, setelah proses pemilihan selesai, masyarakat adat di Yakuhimo berpesta dengan memasak babi serta umbi-umbian di atas batu-batuan besar yang disusun dilubang yang besar, dan seketika itu maka mulailah rakyat berpesta. Bagi masyarakat Yahukimo, pemilu identik dengan pesta gembira. Masyarakat Yahukimo tidak mau terpecah-belah hanya karena berbedanya pilihan, oleh sebab itu, mereka bermusyawarah terlebih dahulu mengenai siapa dan partai apa yang akan mereka pilih.

Oleh karena itu, dengan pertimbangan untuk tetap menjaga dan mempertahankan nilai-nilai adat yang hidup di masyarakat, Mahkamah Konstitusi

${ }^{31}$ Ahmad Zazali, "Pengakuan Negara Terhadap Hak-Hak Politik (Right To Vote) Masyarakat Adat Dalam Pelaksanaan Pemilihan Umum (Studi Putusan Mahkamah Konstitusi No. 47-81/PHPU.A-VII/2009)", Jurnal Konstitusi, Volume 9 Nomor 1, Maret 2012, hlm. 151.

${ }^{32}$ Achmad Sodiki, "Konstitusional Pemilihan Umum Model Masyarakat Yakuhimo”, Jurnal Konstitusi, Volume 6, No. 2, Juli 2009, hlm 1-2. 
dalam putusannya mengakui adanya Noken (hukum adat masyarakat adat di Yahukimo) sebagai cara yang sah dalam perwujudan hak politik dalam pemilu masyarakat hukum adat di Indonesia.

\section{Pengakuan terhadap Hak atas Hutan Adat bagi Masyarakat Hukum Adat (Putusan} No. 35/PUU-X/2012)

Pengakuan terhadap hak atas hutan adat bagi masyarakat hukum adat, berawal dari adanya permohonan uji materi Pasal 1 Angka 6, Pasal 4 ayat (1) dan (2), serta Pasal 5 ayat (1) Undang-Undang No. 41 tahun 1999 tentang Kehutanan. Pasal tersebut pada intinya mengatur tentang hutan adat yang dinyatakan sebagai bagian dari hutan negara. Lirin Colen Dingit, Yoseph Danur, Jilung, Jamaludin, Khairudin, dan Jailan adalah korban dari perampasan dan pembabatan tanah leluhur mereka atas nama negara dan hukum. ${ }^{33}$ Oleh karena itu mereka mengajukan uji materi UU Kehutanan tersebut, bersama dengan Aliansi Masyarakat Adat Nusantara (AMAN), Kesatuan Masyarakat Hukum Adat Kenegerian Kuntu, dan Kesatuan Masyarakat Hukum Adat Kesepuhan Cisitu.

Dalam permohonan uji materi tersebut, terdapat beberapa Pasal yang selama ini dijadikan 'pasal sakti' untuk merampas tanah dari masyarakat hukum adat, yakni Pasal 1 angka 6 UU Kehutanan menyebutkan bahwa "Hutan adat adalah hutan negara yang berada dalam wilayah masyarakat hukum adat". Adanya pengaturan tersebut tentu saja merugikan masyarakat hukum adat dalam hal tanah adat, karena masyarakat hukum adat tak lagi "bebas" menggunakan tanah adatnya, terlebih lagi adanya ketentuan pada Pasal 4 ayat (3) “Pegusaaan hutan oleh negara tetap memperhatikan hak masyarakat hukum adat, sepanjang kenyataannya masih ada dan diakui keberadaannya, serta tidak bertentangan dengan kepentingan nasional.

Pasal 5 megatakan (1) Hutan berdasarkan statusnya terdiri dari: a. Hutan Negara, dan b. Hutan hak. (2) Hutan negara sebagaimana dimaksud pada ayat 1 huruf a, dapat berupa hutan adat. (3) pemerintah menetapkan status hutan sebagaimana dimaksud pada ayat (1) dan ayat (2); dan hutan adat ditetapkan sepanjang menurut kenyataannya masyarakat hukum adat yang bersangkutan masih ada dan diakui keberadaannya.(4) apabila dalam perkembangannya masyarakat hukum adat yang bersangkutan tidak lagi ada, maka hak pengelolaan hutan adat kembali kepada pemerintah. hlm. 8-9.

${ }^{33}$ Achmad Dodi Haryadi, "Hutan Adat, Bukan Hutan Negara”, dalam Majalab Konstitusi, No. 76, Juni 2013, 
Selain itu dalam Pasal 67 ayat (1) dinyatakan bahwa: "masyarakat hukum adat sepanjang menurut kenyataan masih ada dan diakui keberadaannya berhak: a. melakukan pemungutan hasil hutan untuk pemenuhan kebutuhan hidup sehari masyarakat adat yang bersangkutan; b. melakukan kegiatan pengelolaan hutan berdasarkan hutan adat yang berlaku dan tidak bertentangan dengan undangundang; dan; c. mendapatkan pemberdayaan dalam rangka meningkatkan kesejahteraannya. Ayat (2) pengukuhan keberadaan dan hapusnya masyarakat hukum adat sebagaimana dimaksud pada ayat (1) ditetapkan dengan Peraturan Daerah. (3) ketentuan lebih lanjut sebagaimana dimaksud pada ayat (1) dan ayat (2) diatur dengan Peraturan Pemerintah.

Berdasarkan pengaturan tersebut, yang mengatakan bahwa hutan adat sebagai hutan negara, dapat dimaknai sebagai "degradasi" dalam penghormatan dan pengakuan masyarakat hukum adat di Indonesia. Bahkan hutan adat termarjinalkan dan dibiarkan bersaing dengan para pemegang ijin dan pengelola hutan dengan tanpa mendapat kepastian hukum. ${ }^{34}$ Peraturan yang ada saat ini, menempatkan komunitas adat tak ubahnya seperti "tuan-tuan yang terusir dari tanah dan airnya" bahkan, "menjadi tamu di rumahnya sendiri". Bahkan, sepanjang tiga tahun terakhir tercatat 91.968 orang dari 315 komunitas adat masyarakat di Indonesia menjadi korban dalam konflik sumberdaya alam dan pertanahan. Konflik terjadi di 98 kota/ kabupaten di 22 provinsi dengan jumlah konflik mencapai 232 kasus. $^{35}$

Oleh karena untuk mengangkat kembali harkat dan martabat masyarakat hukum adat, Lirin, dkk mengajukan permohonan uji materil terhadap Pasal tersebut pada tahun 2012. Dan sepertinya Lirin, dkk tidak bertepuk sebelah tangan, karena pada 16 Mei 2013 melalui putusan Mahkamah Konstitusi No. 35/PUU-X/2012, yang secara garis besar menyatakan bahwa "hutan adat bukanlah hutan negara". Dalam putusannya Mahkamah Konstitusi berpendapat, keberadaan hutan adat dalam kesatuannya dengan wilayah hak ulayat dari suatu masyarakat hukum adat adalah konsekuensi pengakuan terhadap hukum adat sebagai living law.

Hutan adat dalam kenyataannya berada dalam wilayah hak ulayat. Hak ulayat bagi masyarakat hukum adat, dikuasai dan diusahakan bagi pemenuhan kebutuhan pribadi dan keluarganya saja. Dengan demikian, tidak dimungkinkan hak yang dipunyai oleh warga masyarakat hukum adat tersebut ditiadakan atau dibekukan

\footnotetext{
${ }^{34}$ Ibid, hlm. 10

${ }^{35}$ Loc. Cit.
} 
sepanjang memenuhi syarat dalam cakupan pengertian kesatuan masyarakat hukum adat yang dimaksud dalam Pasal 18B ayat (2) UUD 1945. ${ }^{36}$

Terkait dengan Pasal 5 ayat (1) huruf a, yang mengatakan bahwa 'Hutan negara dapat juga termasuk hutan adat' atau dengan kata lain hutan adat adalah hutan negara. Mahkamah Konstitusi memberikan penjelasan bahwa, tidak dimungkinkan hutan hak berada dalam wilayah hutan negara, atau sebaliknya hutan negara dalam wilayah hutan hak. Sehingga menjadi jelas status dan letak hutan ulayat dalam kaitannya dengan pengakuan dan perlindungan kesatuan-kesatuan masyarakat hukum adat yang dijamin oleh Pasal 18B ayat (2) UUD 1955. Dengan demikian, hutan berdasarkan statusnya dibedakan menjadi dua yaitu hutan negara dan hutan hak. Adapun hutan hak dibedakan antara hutan adat dan hutan perseorangan/badan hukum.

Pasal 18B ayat (2) dan Pasal 28I ayat (3) UUD 1945 merupakan pengakuan dan perlindungan terhadap keberadaan hutan adat dalam kesatuan dengan wilayah hak ulayat suatu masyarakat hukum adat. Hal demikian merupakan konsekuensi pengakuan terhadap hukum adat sebagai living law yang sudah berlangsung sejak lama, dan diteruskan sampai sekarang. Oleh karena itu, menempatkan hutan adat sebagai bagian dari hutan negara merupakan pengabaian terhadap hak-hak msyarakat hukum adat. Dapat disimpulkan bahwa Mahkamah Konstitusi dengan tegas mengatakan bahwa "hutan adat bukanlah hutan negara, maka hutan adat tetaplah hutan adat yang dimiliki oleh masyarakat adat.

\section{Perlindungan Keberadaan Hak Individu dan Hak Ulayat Masyarakat Hukum adat} (Putusan No. 45/PUU-IX/2011)

Mahkamah Konstitusi dalam mewujudkan akses terhadap keadilan bagi masyarakat hukum adat nampaknya tak hanya sekedar mewujudkan keadilan prosedural semata, hal ini dapat dilihat dalam putusan perkara No. 45/PUU-IX/ 2011 mengenai pengujian UU Kehutanan. Mahkamah Konstutusi menegaskan bahwa pengukuhan kawasan hutan harus memperhatikan keberadaan individu dan hak ulayat yang akan berpotensi dirugikan karena proses pengukuhan kawasan hutan. Di banyak kasus, UU Kehutanan dengan frasa 'memperhatikan' tersebut banyak disimpangi, sehingga terjadi berbagai kasus seperti yang telah dipaparkan diatas, yang akhirnya merugikan masyarakat hukum adat, yang bahkan menyebabkan mereka seperti terusir dari rumahnya sendiri.

${ }^{36}$ Lihat lebih lanjut dalam putusan Mahkamah Konstitusi No. 35/PUU-X/2012. 
Oleh karena itu Mahkamah konstitusi memberikan penjelasan dan penegasan terhadap frasa 'memperhatikan hak masyarakat hukum adat' tersebut, yakni: "memperhatikan hak masyarakat hukum adat itu artinya adalah bahwa dalam proses pengukuhan kawasan hutan, harus dilakukan berdasarkan persetujuan dari pihak yang berpotensi dirugikan karena pengukuhan kawasan hutan tersebut. Hal demikian dimaksudkan agar tidak lagi terjadi tafsir sepihak bagi yang berkepentingan terhadap pengukuhan kawasan hutan tersebut.

\section{Penguasaan Hutan bagi Masyarakat Hukum Adat (Putusan No. 34/PUU-IX/2011)}

Permohonan uji materil Undang-Undang No. 41 Tahun 1999 tentang Kehutanan, bermula dari adanya permohonan dari Maskur Anang, yang merupakan warga Jambi Timur, Kota Jambi. Pemohon menganggap dan bahkan telah merasakan hak dan/atau kewenangan konstitusionalnya dirugikan oleh adanya ketentuan dalam Pasal 4 ayat (2) huruf b dan ayat (3) Undang-Undang Nomor 41 Tahun 1999 tentang Kehutanan, yang memberi keleluasaan kepada Menteri Kehutanan untuk menetapkan status wilayah tertentu sebagai kawasan hutan atau kawasan hutan sebagai bukan kawasan hutan, dengan tidak memperhatikan beban hak atas tanah yang telah diberikan oleh negara, sebagaimana terjadi pada tanah milik Pemohon, Menteri Kehutanan secara melanggar hukum melakukan "manipulasi rekayasa alih fungsi" atas areal tanah yang berada di luar kawasan hutan yang peruntukkannya belum ditetapkan sebagai kawasan hutan menjadi “Hutan Cadangan” sebagaimana terjadi pada tanah perkebunan milik Pemohon yang berada pada kawasan Budidaya Pertanian oleh Menteri Kehutanan telah dialih-fungsikan dan ditetapkan sebagai cadangan Hutan Tanaman Industri (HTI), kebijakan tersebut selain melanggar Pasal 5 Peraturan Pemerintah Nomor 7 Tahun 1990 bahwa Menteri Kehutanan tidak mempunyai kewenangan mencadangkan HTI pada kawasan Budidaya Pertanian, hal tersebut jelas sangat merugikan hak, dan/atau kewenangan konstitusional Pemohon sebagaimana dijamin dan diatur dalam Pasal 28A, Pasal 28D ayat (1), Pasal 28G ayat (1) dan Pasal 28H ayat (4) UUD 1945. Selain itu juga, di sekitar lahan tersebut terdapat masharakat hukum adat yang tinggal dalam hutan yang disebut dengan hutan adat. Berdasarkan Pasal 4 ayat (3) disebutkan bahwa "Penguasaan hutan oleh negara tetap memperhatikan hak masyarakat hukum adat, sepanjang kenyataannya masih ada dan diakui keberadaannya, serta tidak bertentangan dengan kepentingan nasional.

Dalam permohonan ini ditemukan bahwa adanya pengalihan fungsi dari perkebunan menjadi hutan cadangan, yang ternyata bukan kewenangan dari Menteri 
Kehutanan untuk melakukan pengalihan fungsi yang merugikan bagi pemohon dan masyarakat hukum adat, karena disekitar lahan tersebut terdapat hutan adat yang merupakan tempat tinggal bagi masyarakat hukum adat tetapi ditetapkan sebagai hutan tanaman industri oleh Menteri Kehutanan. Oleh karena itu, Mahkamah dalam Putusan Nomor 45/PUU-IX/2011, memberi pertimbangan:

"Bahwa dalam suatu negara hukum, pejabat administrasi negara tidak boleh berbuat sekehendak hatinya, akan tetapi harus bertindak sesuai dengan hukum dan peraturan perundang-undangan, serta tindakan berdasarkan freies Ermessen (discretionary powers). Penunjukan belaka atas suatu kawasan untuk dijadikan kawasan hutan tanpa melalui proses atau tahap-tahap yang melibatkan berbagai pemangku kepentingan di kawasan hutan sesuai dengan hukum dan peraturan perundang-undangan, merupakan pelaksanaan pemerintahan otoriter. Penunjukan kawasan hutan merupakan sesuatu yang dapat diprediksi, tidak tibatiba, bahkan harus direncanakan, dan karenanya tidak memerlukan tindakan freies Ermessen (discretionary powers). Tidak seharusnya suatu kawasan hutan yang akan dipertahankan keberadaannya sebagai hutan tetap, menguasai hajat hidup orang banyak, hanya dilakukan melalui penunjukan. ${ }^{37}$

Selain itu, Mahkamah menegaskan kembali bahwa: Pasal 4 ayat (3) UndangUndang Nomor 41 Tahun 1999 tentang Kehutanan bertentangan dengan UndangUndang Dasar Negara Republik Indonesia Tahun 1945 sepanjang tidak dimaknai, "Penguasaan hutan oleh negara tetap wajib melindungi, menghormati, dan memenuhi hak masyarakat hukum adat, sepanjang kenyataannya masih ada dan diakui keberadaannya, hak masyarakat yang diberikan berdasarkan ketentuan peraturan perundang-undangan, serta tidak bertentangan dengan kepentingan nasional", Mahkamah juga mengatakan bahwa "Pasal 4 ayat (3) Undang-Undang Nomor 41 Tahun 1999 tentang Kehutanan, tidak memiliki kekuatan hukum mengikat sepanjang tidak dimaknai, "Penguasaan hutan oleh negara tetap wajib melindungi, menghormati, dan memenuhi hak masyarakat hukum adat, sepanjang kenyataannya masih ada dan diakui keberadaannya, hak masyarakat yang diberikan berdasarkan ketentuan peraturan perundang-undangan, serta tidak bertentangan dengan kepentingan nasional".

Pengukuhan Hak-hak Tradisional Masyarakat Hukum Adat (Putusan No. 3/PUUVIII/2010)

Pengajuan permohonan uji materi terhadap Pasal 1 angka 4, angka 7, dan angka 18, Pasal 16 ayat (1), Pasal 23 ayat (2) dan ayat (4) Undang-Undang Nomor 27 Tahun 2007, berawal dari pemohon yang merasa terdapat tumpang tindih dalam penjelasan

\footnotetext{
${ }^{37}$ Lihat lebih lanjut dalam putusan Mahkamah Konstitusi No. 34/PUU-IX/2011.
} 
objek hak pengelolaan perairan pesisir (HP-3) dengan peraturan perundangundangan yang lain yakni Undang-Undang Nomor 5 Tahun 1960 tentang Peraturan Dasar Pokok-Pokok Agraria sehingga menimbulkan ketidakpastian hukum dan bertentangan dengan Pasal 28D ayat (1) UUD 1945. Terdapat kerancuan atau tumpang tindih antara objek HP-3 tersebut dengan objek perizinan di bidang kehutanan, pertambangan, dan pariwisata.

Tumpang tindih objek tersebut di antaranya adalah: (1) antara HP-3 dengan perizinan bidang kehutanan yaitu tentang pemanfaatan hutan mangrove, fauna/flora yang terdapat di kawasan perairan pantai, dan penggunaan jasa lingkungan di kawasan hutan mangrove tersebut; (2) antara HP-3 dengan perijinan bidang pertambangan yaitu pemanfaatan pasir sebagai sumber daya di kawasan pantai dan mineral dalam laut; (3) antara HP-3 dengan perizinan bidang pariwisata yaitu pengembangan wisata pantai; Di samping itu, karena luas cakupan objek HP-3 terutama yang terkait dengan pemanfaatan daratan (permukaan bumi yang disebut tanah) maupun tubuh bumi, termasuk yang di bawah air, maka terjadi tumpang tindih dengan objek pengaturan di bidang pertanahan. Selama ini, dalam praktik telah diberikan hak atas tanah sesuai (UUPA) yang dapat berupa Hak Guna Bangunan (HGB), di wilayah dermaga dan perairan pantai, rumah-rumah nelayan dan pelatarannya, bangunan-bangunan di perairan pesisir; Hak Guna Usaha (HGU) diberikan untuk budidaya perikanan pantai, keramba ikan, budidaya rumput laut, budidaya mutiara. Bahwa terdapat potensi tumpang tindih HP-3 dengan pemberian hak atau perizinan oleh instansi/sektor lain, hal ini yang jika diberlakukan akan mereduksi keberadaaan masyarakat hukum adat yang berada di daerah pesisisr ataupun pulau-pulau kecil, bahkan dapat terusir akibat adanya pemberian hak pengelolaan perairan dan pesisir. Oleh karena itu dalam putusan perkara No. 3/PUU-VIII/2010 mengenai pengujian Undang-Undang Pengelolaan Wilayah Pesisir dan Pulau-pulau Kecil, Mahkamah Konstitusi menyatakan bahwa 'pembatasan waktu tertentu dalam pemberian hak pengelolaan perairan pesisir (HP3) bertentangan dengan Pasal 18B UUD 1945'. Hal ini dikarenakan tidak sesuai dengan konsep hak ulayat dan hak-hak tradisional rakyat yang tidak bisa dibatasi karena secara karakteristik, hak tersebut dapat dinikmati secara turun temurun bagi masyarakat hukum adat.

Mahkamah Konstitusi dalam putusan tersebut juga berpendapat bahwa pemberian HP3 kepada individu dan badan hukum swasta juga mengancam keberadaan hak-hak masyarakat tradisional dan kearifan masyarakat lokal atas 
wilayah pesisir dan pulau-pulau kecil, karena menurut konsepsi undang-undang tersebut, masyarakat tradisional yang secara turun temurun memiliki hak atas pemanfaatan perairan, pesisir dan pulau-pulau kecil akan diberikan HP3, dan dapat menerima ganti rugi atas pemberian HP3 kepada swasta berdasarkan kesepakatan musyawarah. Menurut Mahkamah Konstitusi konsep yang demikian akan membatasi hak-hak tradisional masyarakat dalam batasan waktu tertentu menurut pemberian HP3 yaitu 20 tahun dan dapat diperpanjang. Terkait dengan pemberian ganti kerugian, menurut Mahkamah Konstitusi berpendapat akan menghilangkan hak-hak tradisional atas wilayah pesisir dan pulau-pulau kecil, akan menghilangkan hak-hak tradisional masyarakat hukum adat yang seharusnya dinikmati secara turun temurun (just saving principle), karena dengan pemberian ganti kerugian maka hak tersebut hanya dinikmati oleh masyarakat penerima ganti kerugian pada saat itu saja.

\section{Penutup}

Berdasarkan pada pembahasan di atas, maka dapat ditarik dua kesimpulan, yakni: pertama, bahwa keberadaan masyarakat hukum adat di Indonesia telah diakomodir di berbagai lingkup pengaturan, baik dalam UUD 1945, UndangUndang, Peraturan Daerah, Surat Keputusan Gubernur, dan Surat Keputusan Bupati. Kedua, politik hukum masyarakat hukum adat melalui putusan Mahkamah Konstitusi, terlihat memperkokoh keberadaan masyarakat hukum adat di Indonesia dengan memberikan berbagai tafsir atau penjelasan yakni (1) menjelaskan untuk pertama kalinya mengenai empat syarat dasar konstitusional masyarakat hukum adat, (2) Mahkamah Konstitusi mengakui Noken (hukum adat masyarakat adat di Yahukimo) sebagai cara yang sah dalam perwujudan hak politik dalam pemilu masyarakat hukum adat, (3) Mahkamah Konstitusi dengan tegas mengatakan bahwa "hutan adat bukanlah hutan negara, (4) Mahkamah Konstitusi member penjelasan dan penegasan terhadap frasa 'memperhatikan' yakni: "memperhatikan hak masyarakat hukum adat itu artinya adalah bawa dalam proses pengukuhan kawasan hutan, harus dilakukan berdasarkan persetujuan dari pihak yang berpotensi dirugikan karena pengukuhan kawasan hutan tersebut, (5) Mahkamah Konstitusi menegaskan bahwa "Penguasaan hutan oleh negara tetap wajib melindungi, menghormati, dan memenuhi hak masyarakat hukum adat, sepanjang kenyataannya masih ada dan diakui 
keberadaannya, hak masyarakat yang diberikan berdasarkan ketentuan peraturan perundangundangan,serta tidak bertentangan dengan kepentingan nasional". (6) Mengakui wilayah hak ulayat dari suatu masyarakat hukum adat adalah konsekuensi pengakuan terhadap hukum adat sebagai living law (Mahkamah Konstitusi mempertegas Pasal 18B UUD 1945, bahwa masyarakat hukum adat dalam penguasaan hak ulayat merupakan hak tradisional yang tidak dapat dibatasi oleh peraturan perundangundangan karena hak-hak tradisional masyarakat hukum adat yang seharusnya dinikmati secara turun temurun (just saving principle).

\section{Daftar Pustaka}

AM., Sjahmunir, Pemerintahan Nagari dan Tanah Ulayat, Andalas University Press, Padang, 2006.

A. Poster, Richard, The Problem of Jurisprudence, New York, Harvard University Press, 1995.

Arizona, Yance, “Mahkamah Konstitusi Sebagai Arena Memperjuangkan Hak-Hak Warga Negara Atas Tanah dan Sumber Daya Alam Lainnya", disampaikan dalam Konferensi Nasional Mahkamah Konstitusi dan Perlindungan Hak Warga Negara, Jakarta, 18-19 November 2013.

Asshiddiqie, Jimly, Mahkamah Konstitusi dan Cita Negara Hukum Indonesia, opini, http/ / www.pemantauperadilan.com.

Bahar, Saafroedin dan Ruswiati Suryasaputra, Perlindungan Hak Konstitusional Masyarakat Hukum Adat, Sekretariat Nasional Masyarakat Hukum Adat, Pekanbaru, 2009.

Barents, J., Ilmu Politik: Suatu Perkenalan Lapangan, Jakarta: PT. Pembangunan, 1958.

Djohanjah, "Akses Pada Keadilan”, Makalah pada Penelitian HAM bagi jejaring Komisi Yudisial, Bandung, 3 Juli 2010.

Dodi Haryadi, Achmad, "Hutan Adat Dalam Daulat Masyarakat Hukum Adat", Majalah Konstitusi, No 76, Juni 2012.

Kelompok Kerja Akses Terhadap Keadilan, Strategi Nasional Akses terhadap Keadilan, BAPPENAS Derektorat Hukum dan HAM , Jakarta, 2009.

Mahmud, Peter, Penelitian Hukum, Kencana, Jakarta, 2005.

Manan, Bagir, Menyongsong Fajar Otonomi Daerah, Cetakan kedua, PSH FH UII, Yogyakarta, 1999.

Nonet, Phillppe dan Philip Selznick, Law and Society in Transition Towards Responsive Law, New Jersey: Trascation Publishers, 2001.

Raharjdjo, Satjipto, Hukum Progresif(Sebuah Sintesa Hukum Indonesia), Genta Publishing, Cetakan I, Yogyakarta, Juli 2009. 
Riyadi, Eko, (editor), To Promote: Membaca Perkembangan Wacana Hak Asasi Manusia di Indonesia, PUSHAM UII, Yogyakarta, 2012.

, dan Syarif Nur Hidayat (editor), Vulnerable Groups: Kajian dan Mekanisme Pelindungannya, Cetakan Pertama, Pusat Studi Hak Asasi Manusia Universitas Islam Indonesia (PUSHAM UII), Yogyakarta, 2012.

S. Davidson, Jamie, dkk, Adat Dalam Politik Indonesia, Yayasan Obor Indonesia, Edisi1, KITLV-Jakarta, 2010.

Sina Chandranegara, Ibnu, “Ultra Petita Dalam Pengujian Undang-Undang dan Jalan Mencapai Keadilan Konstitusional", Jurnal Konstitusi, Volume 9 Nomor 1, Maret 2012.

Seokanto, Soerjono, Kedudukan Kepala Desa Sebagai Hakim Perdamaian, Cet. Pertama, Rajawali Press, Jakarta, 1986

Simarmata, Rikardo, Menyongsong Berakhirnya Abad Masyarakat Adat: Resistensi Pengakuan Bersyarat, 2004.

Sodiki, Achmad, "Konstitusional Pemilihan Umum Model Masyarakat Yakuhimo”, Jurnal Konstitusi, Volume 6, No. 2, Juli 2009.

Thontowi, Jawahir, "Perlindungan dan Pengakuan Masyarakat Hukum Adat dan Tantangannya dalam Hukum Indonesia", Jurnal Hukum Ius Qua Iustum No. 1 Vol. 20 Januari, Yogyakarta, 2013.

Wayan Wesna Astara, I, Pertarungan Politik Hukum Negara dan Politik Kebudayaan (Otonomi Desa Adat di Bali), Udayana University Press, Bali, 2010.

Wignjodipuro, Surojo, Pengantar Azas-azas Hukum Adat, Ed. II, Alumni, Bandung, 1973.

Putusan Mahkamah Konstitusi Nomor. 31/PUU-V/2007.

Putusan Mahkamah Konstitusi Nomor. 47-81/PHPU.A/VII/ 2009.

Putusan Mahkamah Konstitusi Nomor. 3/PUU-VII/2010.

Putusan Mahkamah Konstitusi Nomor. 45/PUU-IX/2011

Putusan Mahkamah Konstitusi Nomor. 35/PUU-X/2012.

Tempo, Senin, 28 Oktober 2013, id.berita.yahoo.com/korban-konflik-pertanahancapai-91-968-orang-073753758.html. 